\title{
TRILHAS INTERPRETATIVAS COMO INSTRUMENTOS DE GEOTURISMO E GEOCONSERVAÇÃO: Caso da trilha do Salto São Jorge, Campos Gerais do Paraná
}

\author{
Ana Cláudia Folmann \\ Bacharel em Turismo, Mestre em Geografia - UEPG \\ acfolmann@hotmail.com \\ Maria Ligia Cassol Pinto \\ Geógrafa, Doutora em Geografia - UEPG \\ ligialih@brturbo.com.br \\ Gilson Burigo Guimarães \\ Geólogo, Doutor em Petrologia - UEPG \\ gburigo@ig.com.br
}

\section{Resumo}

As trilhas interpretativas têm se destacado no contexto do turismo como uma ferramenta valiosa na conservação do patrimônio natural. Uma modalidade de turismo que tem ganhado cada vez mais adeptos é o Geoturismo. Este trabalho pretende mostrar a importância das trilhas como um instrumento de geoturismo e geoconservação, quando equipadas com os meios interpretativos adequados. O Salto São Jorge, no município de Ponta Grossa - PR destaca-se devido à exposição do contato geológico raro, constituído por rochas da Formação Furnas, Formação Iapó e Complexo Granítico Cunhaporanga. O geossítio ainda apresenta atrativos arqueológicos e históricos, e é muito procurado para a prática de atividades de lazer e esporte. A forma com que a atividade turística tem se realizado (muitas vezes caracterizada como turismo de massa) vem causando impactos ao patrimônio natural, inclusive com ameaças à geodiversidade. Para reverter tal situação e colaborar para que os visitantes possam obter, além da apreciação estética, conhecimentos geológicos sobre o ambiente, são propostos alguns pontos de interpretação no percurso da trilha e melhorias da mesma.

Palavras chave: Trilhas interpretativas, Geoturismo, Educação ambiental, Geoconservação, Geodiversidade.

\section{Abstract}

The interpretative trails have stood in the tourism context as a valuable tool in the natural patrimony conservancy. A modality of tourism that has gained more and more adepts is the Geotourism. This work intends to show the importance of the trails as an instrument of geotourism and geoconservancy, if equipped with the adequates interpretative mids. The Salto São Jorge, in the borough of Ponta Grossa - PR stands up due to the exposition of the rare geological contact constituted by rocks of the Furnas Formation, Iapó Formation and the Cunhaporanga Complex. The geosite even presents archaeological and historical attributes and it's visited for the sport practice and leisure. The way that tourism has been made (often characterized as mass tourism) is causing impacts to natural heritage, including threats to geodiversity. To reverse that situation and contribute to the visitors can have esthetic appreciation and geological knowledge about the environment; some proposals of interpretative points in the trail are suggested and trail's improvements.

Key words: Interpretative trails, Geotourism, Environmental education, 
Geoconservancy, Geodiversity.

Introdução

A atividade turística tem crescido intensamente nas últimas décadas e tem conquistado cada vez mais espaço e representatividade na economia global. Esta atividade pode ser considerada causadora de degradação ambiental e, ao mesmo tempo, um modo de proteção do meio ambiente.

Em alguns lugares, principalmente nos países do hemisfério sul, o turismo surge como uma opção econômica sustentável, substituindo atividades de extrativismo que comprometem os recursos naturais de forma irreversível. Já em outros casos, o turismo de massa faz com que locais sejam ameaçados devido, entre outros, à poluição, acabando com a matéria prima que atrai os turistas.

O turismo de massa em áreas naturais tem sido amplamente criticado e apontado como causador de inúmeros impactos ambientais. O que seria capaz de provocar significativa mudança em relação a esse tipo de turismo é a organização do espaço turístico, e principalmente, a intensificação da educação ambiental dos visitantes. De acordo com Rodrigues (1997) essas ações educativas devem levar à conscientização de que cada indivíduo tem sua responsabilidade no comportamento coletivo.

Uma das localidades que se destaca na região dos Campos Gerais do Paraná, devido ao belíssimo patrimônio natural e à geodiversidade é o canyon do rio São Jorge, no município de Ponta Grossa. Muito procurado para a prática de esportes, lazer e turismo, esse sítio, que faz parte de uma unidade de conservação (categorias Parque Municipal, Área de Proteção Ambiental e Parque Nacional) tem recebido poucos cuidados relacionados à conservação ambiental, especialmente a trilha que vai de encontro ao Salto São Jorge.

O Salto São Jorge é uma das principais atrações turísticas naturais da cidade. Apesar do elevado número de aspectos relevantes para uso didático, o local ainda é pouco utilizado com essa finalidade. A interpretação ambiental, por meio das trilhas, seria de grande valia para o local, pois essas trilhas são os meios mais propícios à disseminação da educação ambiental.

As trilhas de interpretação da natureza são caminhos estabelecidos, com diferentes formas, comprimentos e larguras, que possuam o objetivo de aproximar o 
visitante do ambiente natural, ou conduzi-lo a um atrativo específico, possibilitando seu entretenimento ou educação através de sinalizações ou de recursos interpretativos (SALVATI, 2003).

As caminhadas em trilhas são o meio de deslocamento mais antigo do homem, e hoje constituem um atrativo para aqueles que buscam maiores experiências e vivências na natureza. As trilhas também têm fundamental importância para o turismo, pois são o meio pelo qual as pessoas chegam aos atrativos turísticos. Em alguns casos, as trilhas são os próprios atrativos em uma unidade de conservação.

As unidades de conservação de uso público são os locais onde as trilhas são mais representativas e para onde convergem os visitantes que procuram, através delas, os ambientes naturais para turismo, lazer e prática de esportes (COSTA, 2006).

O presente trabalho enfoca o turismo relacionado às rochas, relevo, água, fósseis, arqueologia, solos, entre outros, denominado “Geoturismo”. O Geoturismo é um novo segmento do turismo que tem se destacado atualmente. De acordo com Hose (1995 apud NASCIMENTO et al, 2008. p.40) o Geoturismo é

\footnotetext{
a provisão de facilidades interpretativas e serviços para promover o valor e os benefícios sociais de lugares e materiais geológicos e geomorfológicos e assegurar sua conservação, para uso de estudantes, turistas e outras pessoas com interesse recreativo ou de lazer.
}

Este tipo de turismo tem na geodiversidade um grande atrativo para as trilhas interpretativas, além de ser uma maneira de conservar o patrimônio geológico existente e de disseminar práticas de educação ambiental.

Em muitos parques e unidades de conservação as trilhas existentes não são tão bem aproveitadas quanto deveriam, pois não há infra-estrutura, sinalização, adaptações aos portadores de necessidades especiais, nem meios interpretativos sobre a biodiversidade local, muito menos sobre os processos geológicos e geomorfológicos formadores da paisagem. A falta de painéis interpretativos, folhetos ou guias para conduzir as visitações faz com que sejam desperdiçadas oportunidades de aprendizado e interpretação ambiental.

Conhecer aspectos relativos às geociências, aos processos formadores das paisagens e dos elementos da geodiversidade auxilia o entendimento da história da 
Terra, e consequentemente, da história do próprio ser humano.

No meio ambiente tudo está interligado, e a visão fragmentada que comumente é ensinada nas escolas só faz distanciar as pessoas da natureza e dificultar a compreensão do valor e sentido da vida.

Para que haja uma aproximação entre as pessoas e o meio ambiente é importante que haja uma educação ecológica, que as aulas do ensino fundamental ao superior possam ocorrer também em ambientes naturais, que as atividades turísticas promovam a sensibilização e identificação com a natureza; e, nesse sentido, as trilhas interpretativas são peças fundamentais.

Entender os processos de formação das paisagens é muito importante para que os turistas possam estar sensibilizados a conservar o patrimônio natural. Esse entendimento nem sempre é fácil, já que muitas vezes as informações geológicas e geomorfológicas não estão disponíveis em linguagem acessível.

Nesse contexto, o objetivo geral desse trabalho é analisar a importância das trilhas como instrumentos de geoturismo e geoconservação, a partir do estudo da trilha do Salto São Jorge. Os objetivos específicos consistem em:

- oferecer subsídios para um ordenamento das visitações e um manejo adequado da trilha em relação à educação ambiental, geoturismo e geoconservação, por meio de propostas de melhorias nas trilhas e na infraestrutura da unidade de conservação;

- colaborar com o desenvolvimento do geoturismo, através da divulgação desse estudo;

- contribuir com o aprofundamento dos estudos relativos à geoconservação dos Campos Gerais do Paraná, buscando a disseminação dos conhecimentos geológicos à comunidade.

\section{Metodologia}

Fizeram parte da metodologia da pesquisa o levantamento bibliográfico; investigações de campo com uma equipe multidisciplinar; a espacialização, com auxílio de um receptor GPS (Global Positioning System) Garmin, modelo Etrex Vista HCx, Universal Transversa de Mercator datum SAD69, da extensão da trilha e dos principais pontos de interesse (os dados foram plotados no software MapSource, enquanto que o 
mapa foi elaborados com o uso do software Arc View 3.2); e o aprofundamento das informações, por meio de entrevistas informais com frequentadores da trilha, pessoas que trabalham em sua manutenção, entre outras.

Caracterização da área de estudo: Bacia Hidrográfica do rio São Jorge

A bacia do São Jorge (figura 1) está inserida na Área de Proteção Ambiental (APA) da Escarpa Devoniana, além de estar dentro dos limites do Parque Nacional dos Campos Gerais, decretado em 2006, porém ainda não implantado.

O relevo caracteriza-se por seus contrastes, há terrenos planos e encostas abruptas, verticalizadas. Diferentes ecossistemas como campos, floresta de araucária e refúgios de cerrado fazem parte desta paisagem.

Os solos na área do Salto São Jorge são delgados e arenosos e, muitas vezes, expõem o substrato rochoso; são provenientes do intemperismo do Arenito Furnas.

O geossítio Salto São Jorge é um patrimônio natural de relevância turística, científica e pedagógica. Lá são encontradas formas singulares de relevo como cachoeiras, lajeados, relevos ruiniformes, cascatas, escarpas, canyons, fendas, lapas e cavernas. 


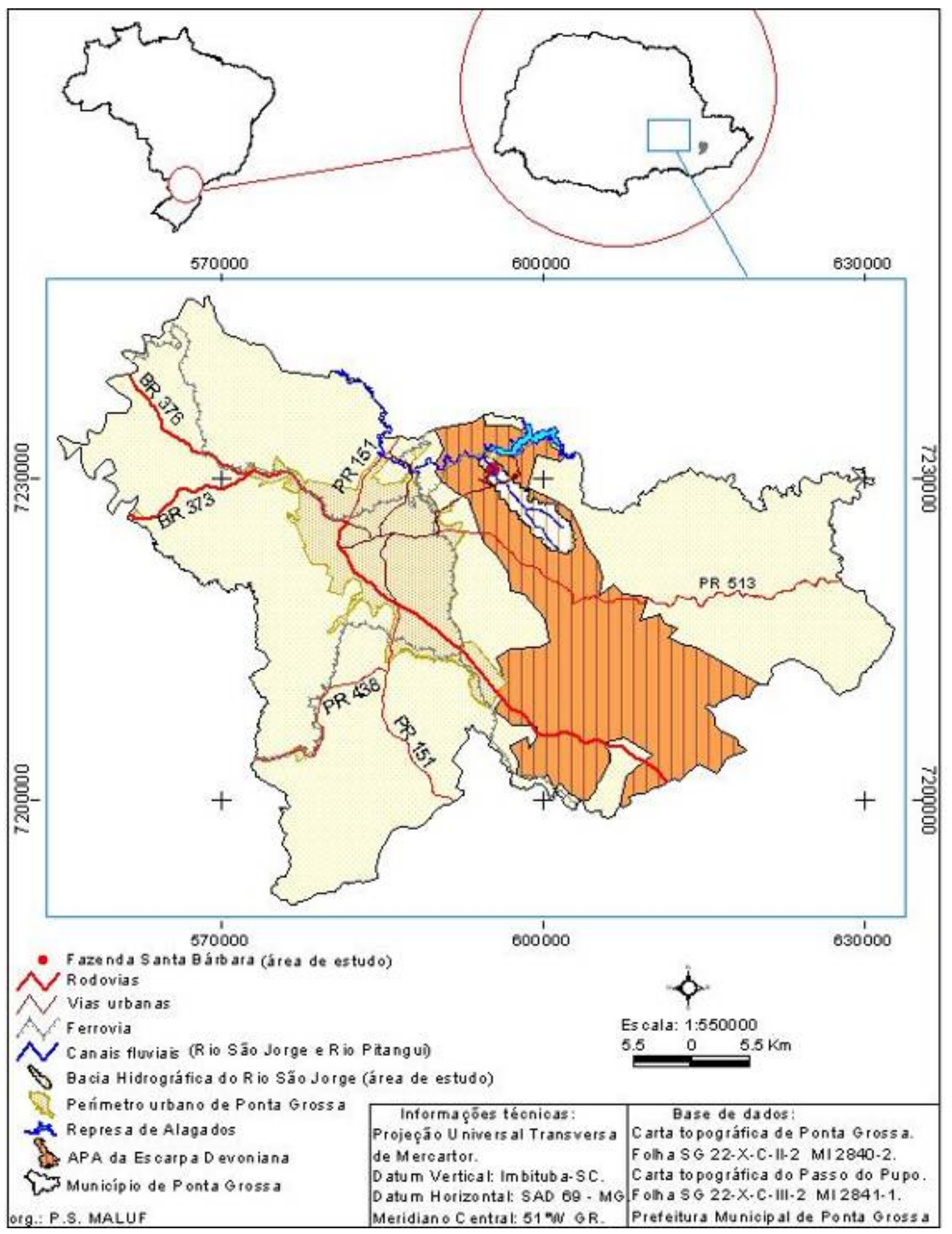

Figura 1 - Localização da área de estudo: Bacia Hidrográfica do rio São Jorge

Ameaças à bio e à geodiversidade são observadas, como uso de agrotóxicos na plantação próxima ao rio, descarte de resíduos, poluição das águas do rio, pichações e 
fogueiras em locais inadequados. A fuligem dessas fogueiras recobriu pinturas rupestres com mais de dez mil anos de idade.

No local da cachoeira, em um desnível topográfico de cerca de $40 \mathrm{~m}$, aparecem da base para o topo: (1) o embasamento da Bacia do Paraná, ali representado por granitóide porfirítico do Complexo Granítico Cunhaporanga; (2) diamictitos da Formação Iapó e (3) conglomerados e arenitos da Formação Furnas (figura 2).

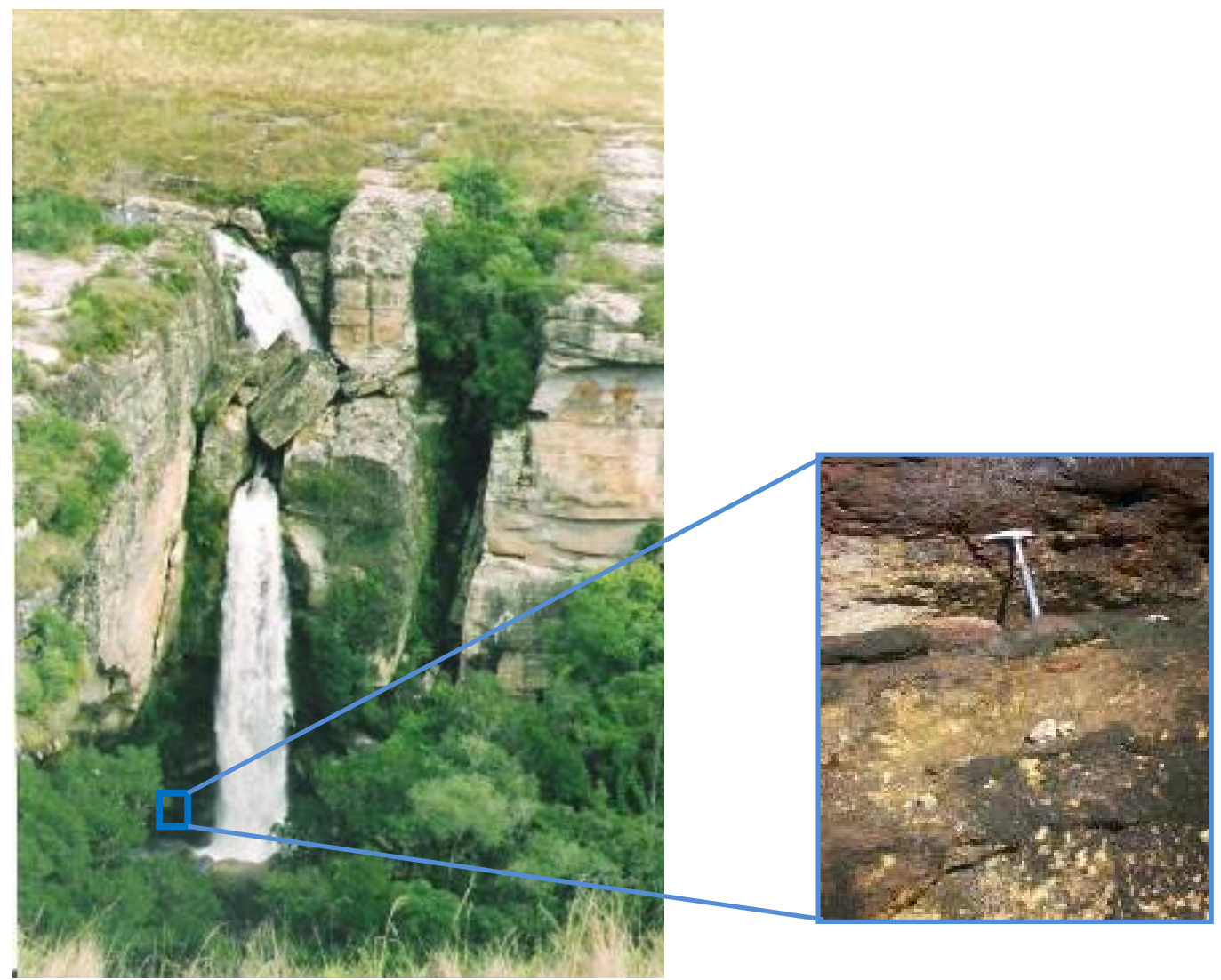

Figura 2 - Salto São Jorge e detalhe do contato entre o Complexo Granítico Cunhaporanga e a Formação Iapó

Fonte: Prieto, 2004; Folmann, 2010

O Complexo Granítico Cunhaporanga está localizado sob as formações Furnas e Iapó, ele ocupa uma extensa área alongada na direção NE, desde a região dos Alagados (limite dos municípios de Ponta Grossa e Castro) até bem próximo à divisa PR-SP ao sul de Itararé, sendo a sudoeste e norte-noroeste coberto pela Formação Furnas através de discordância inconforme. As rochas dessa unidade granítica 
testemunham magmatismo do final do Ciclo Brasiliano, de idade neoproterozóica (GUIMARÃES, 1995, citado por MASSUQUETO et al, 2009).

Já a Formação Iapó é resultante da glaciação no limite Ordoviciano/ Siluriano e apresenta sequência basal de pequena espessura (geralmente inferior a $20 \mathrm{~m}$ ), de natureza descontínua, que se assenta diretamente sobre o embasamento. (ASSINE et al, 1998).

Há muito poucos afloramentos desta formação, que ocorre sotoposta aos arenitos conglomeráticos e conglomerados da base da Formação Furnas. Existe seixos caídos, o que caracteriza a presença de material transportado por gelo flutuante. A formação tem $2 \mathrm{~m}$ de espessura, e é composta de diamictitos com seixos polimíticos facetados e estriados (ASSINE et al, 1998).

As rochas da Formação Furnas (Siluriano a Devoniano Inferior) são as mais jovens, estas aparecem no topo e configuram a maior parte da cachoeira do São Jorge. A Formação Furnas é constituída por arenitos quartzosos brancos, de granulação média a grossa, feldspáticos e/ou caulínicos, mal selecionados. (ASSINE, 1999, p. 357).

O Arenito Furnas, como também é chamada esta Formação do Grupo Paraná, é composto por rochas originadas desde o final do Siluriano até o início do Devoniano, provavelmente em ambientes transicionais marinhos rasos ou fluvio-marítimos. Uma de suas características são as estratificações cruzadas que apresenta.

Por proporcionar a visualização da geodiversidade, representada por rochas de três períodos diferentes, e estimular o entendimento da sua história geológica, este local é considerado um laboratório de geologia ao ar livre.

\section{Desvendando a trilha do Salto São Jorge}

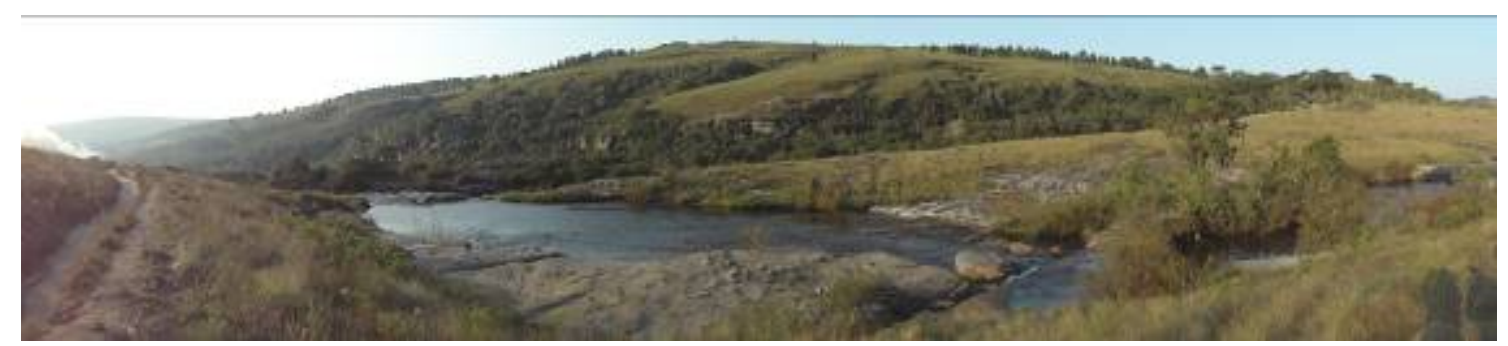

Figura 3 - A trilha apresenta possibilidades de abordar diversos elementos didáticos, além da contemplação das paisagens às margens do rio São Jorge. 
Fonte: Folmann, 2010

A trilha está localizada em uma propriedade particular chamada Fazenda Santa Bárbara. A fazenda possui alguma infra-estrutura como banheiros, churrasqueiras, lixeiras, mesas, bancos, área para camping e lanchonete, porém são muito precários, e não se encontram em bom estado de conservação. São cobradas taxas para entrada e acampamento no local.

A forma da trilha é linear, com dois braços de trilha para mirantes/ atrativos, e sua extensão é de $788 \mathrm{~m}$. O grau de dificuldade pode ser considerado de nível leve quanto à intensidade, e com obstáculos naturais, quanto ao nível técnico, de acordo com a classificação citada por Andrade (2004).

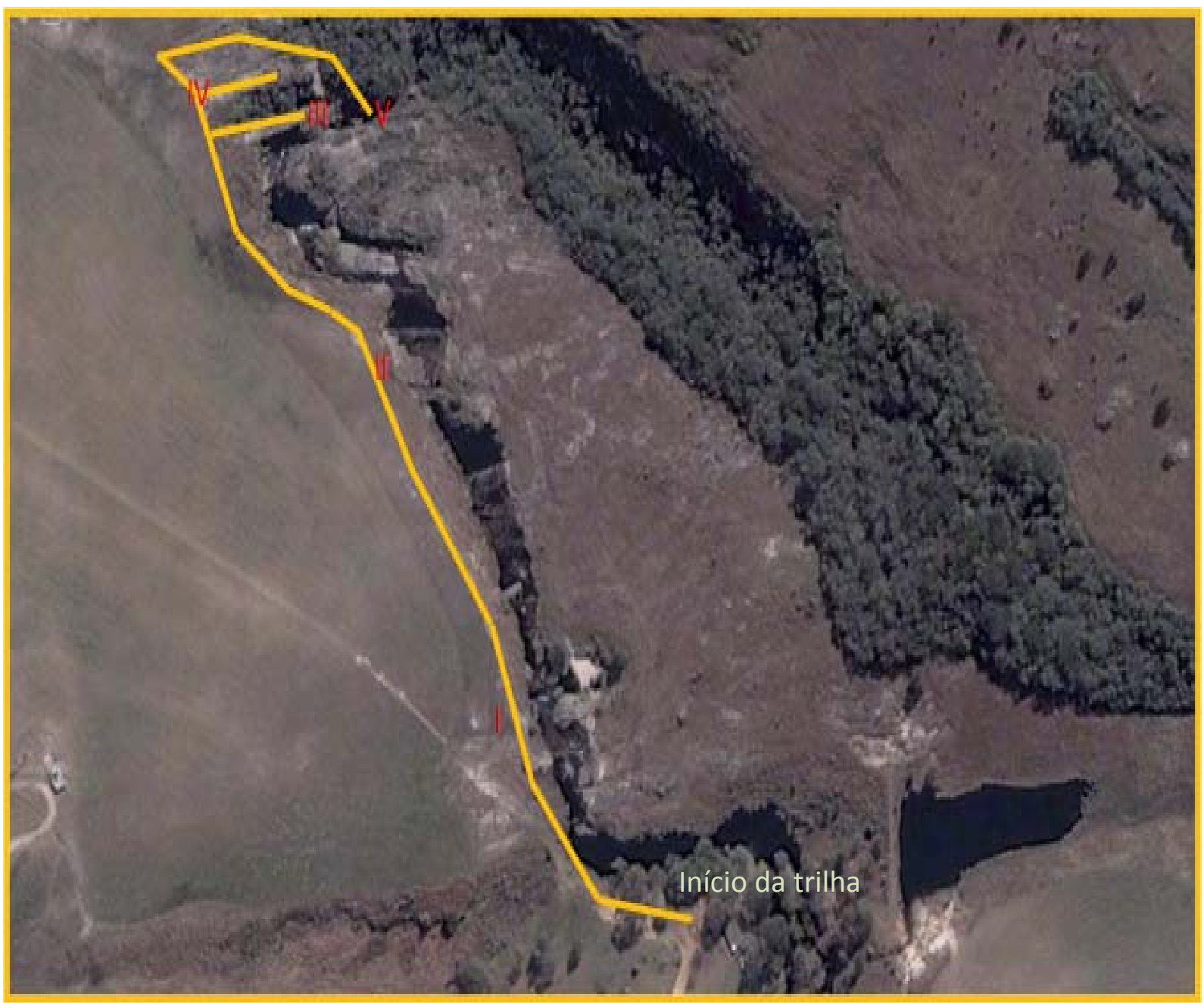

Figura 4 - Traçado da trilha do Salto São Jorge (em cor amarela). Os algarismos romanos representam os locais com potencial para interpretação.

Geo UERJ - Ano 12, nº. 21, v. 2, $2^{\circ}$ semestre de 2010. www.geouerj.uerj.br/ojs ISSN 1981-9021 
Fonte: Baseado em imagem de Google Earth, 2006

Para que haja, além da apreciação estética, possibilidade de compreensão da história geológica do local, alguns pontos de interpretação são propostos ao longo da trilha (figura 4).

Tais pontos foram estabelecidos buscando dar visibilidade aos atrativos que realçam a beleza cênica do local, e favorecem a compreensão dos processos de formação da paisagem. Estão incluídos diferentes feições de relevo, características da geodiversidade local, e efeitos da ação da água dos rios (quadro 1).

A trilha tem atrativos interessantes para distintos tipos de público, com variadas faixas etárias e oferece também oportunidade de aprendizado específico para grupos de estudantes das áreas de geografia, biologia, geologia, turismo, alunos de ensino médio e fundamental.

Quadro 1 - Relação entre os pontos de interpretação e assuntos de interesse geoturístico

\begin{tabular}{|c|c|}
\hline $\begin{array}{c}\text { Pontos de } \\
\text { interpretação }\end{array}$ & $\begin{array}{c}\text { Exemplos de assuntos que podem } \\
\text { ser explorados na interpretação }\end{array}$ \\
\hline I & $\begin{array}{r}\text { Solos, ciclo das rochas, diagênese, tectonismo, falhas e fraturas, } \\
\text { estratificação, evolução do Arco de Ponta Grossa. }\end{array}$ \\
\hline II & $\begin{array}{r}\text { Processos erosivos; Organização das camadas do Arenito Furnas nas } \\
\text { paredes rochosas. }\end{array}$ \\
\hline III & $\begin{array}{r}\text { Feições e micro-feições de relevo; intemperismo químico e } \\
\text { biológico; relevo ruiniforme; falha geológica; processo de formação }\end{array}$ \\
\hline IV & Evolução das vertentes, rupturas de nível e divisores de águas; \\
& granulometria dos sedimentos. \\
\hline V & Geodiversidade; contato geológico. \\
\hline
\end{tabular}


Mas para que as visitações tenham qualidade, e para que a trilha não seja demasiadamente impactada, de forma a comprometer seus recursos, é preciso avaliar a capacidade de suporte da trilha. Optou-se por utilizar o método de avaliação proposto por Cifuentes (1999), com pequenas adaptações devido às especificidades da trilha do Salto São Jorge. Utilizando-se algumas fórmulas, a capacidade de carga física é calculada, e a partir dela, calcula-se a capacidade de carga real. Para isso foram levados em conta os seguintes fatores: fator social; erodibilidade; acessibilidade; precipitação; fechamentos temporais; e alagamento.

As áreas de maior declividade (figura 4) mereceram especial atenção em relação aos impactos que o pisoteamento pode trazer, pois apresentam maior risco de erodibilidade.

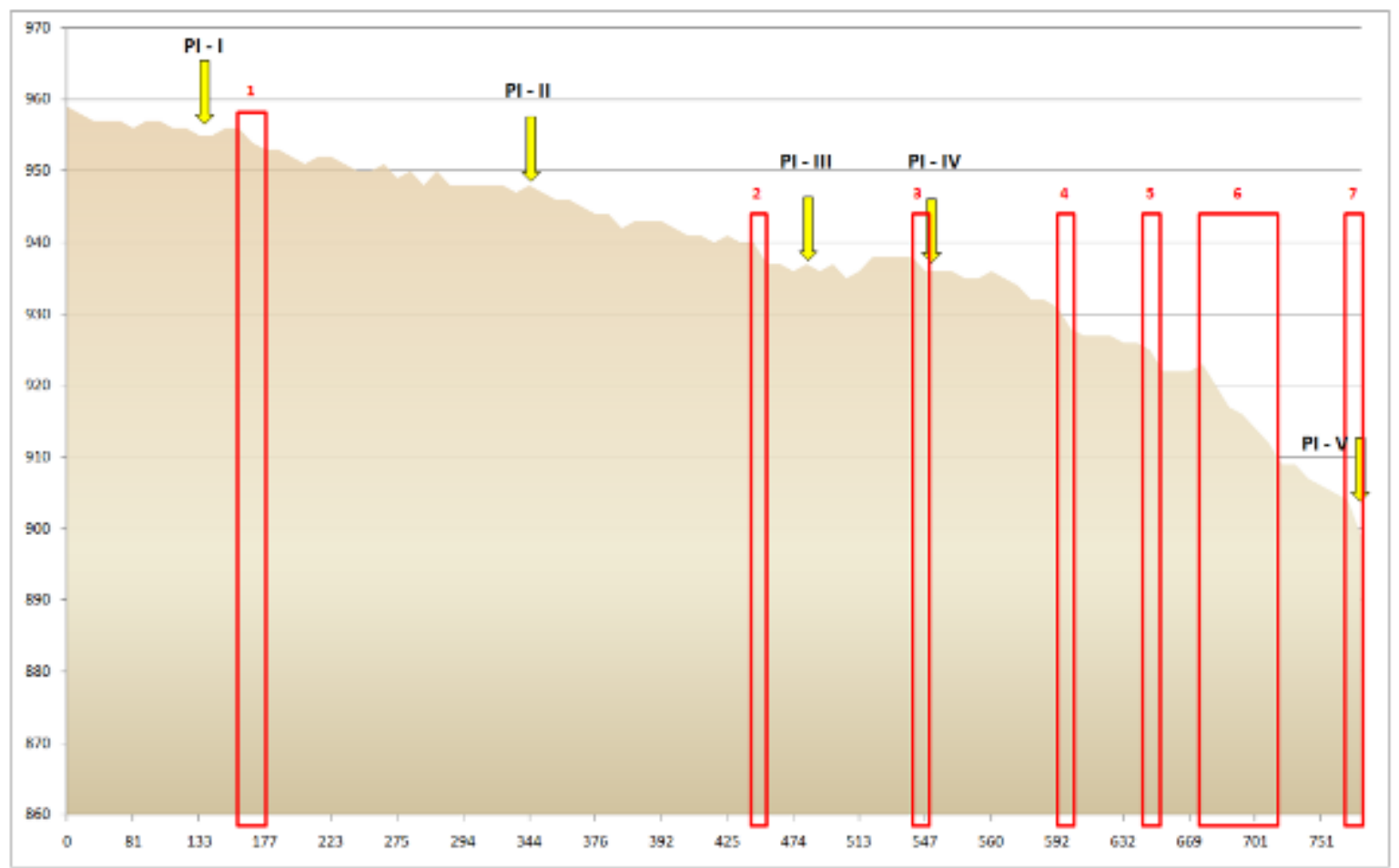

Figura 4 - Perfil altimétrico da trilha Salto São Jorge. Os retângulos em vermelho representam os locais de maior declividade. (As setas em amarelo indicam os pontos de interpretação.)

A capacidade de suporte da trilha seria de 129 pessoas por dia, se a capacidade de manejo (requisitos ligados à infra-estrutura, recursos humanos e equipamentos) fosse 
de 100\%. Atualmente o geossítio não conta com infra-estrutura condizente com a paisagem, nem com profissionais qualificados.

A trilha recebe centenas de pessoas, muitas vezes, mais de 400 visitas nos dias dos finais de semana de verão. Essa quantidade extrapola a capacidade da trilha para uma boa visitação. A tendência, nesse caso, é que aumentem progressivamente os processos erosivos que a degradam e que a qualidade das visitas seja comprometida.

A avaliação da capacidade de suporte turístico é relativa, e não deve ser considerada como a solução para os problemas decorrentes do impacto dos visitantes na trilha. Por isso ressalta-se a importância de um plano de educação ambiental como parte do plano de manejo do parque nacional, além de investimentos na infra-estrutura, recursos humanos e equipamentos de segurança.

Da geodiversidade ao turista

Talvez por não entender os processos de formação da paisagem visitada, e consequentemente, não dar o devido valor a ela, as pessoas tenham um comportamento depreciativo. Há muito lixo espalhado, pichações nas rochas e sinais de fogueira em locais impróprios. Além disso, o tipo de público que freqüenta o rio São Jorge, muitas vezes, traz para este ambiente os hábitos urbanos que possui. Alguns optam por fazer churrasco, consumir bebidas alcoólicas e fazer uso de equipamentos sonoros em alto volume.

As trilhas interpretativas são um ótimo ambiente para trabalhar estas questões ambientais porque as pessoas estão em contato direto com a natureza, e com os problemas que a falta de cuidados com ela pode ocasionar.

Para que a educação ambiental atinja seus objetivos no caso da caminhada na trilha do Salto São Jorge, é importante que haja meios interpretativos como painéis ou folhetos de boa qualidade técnica; ou ainda, que um guia exerça a função de explicar e alertar o visitante para a questão ambiental. A qualificação do profissional faz toda a diferença neste momento - o guia deve ter estar bem preparado para poder transmitir a informação correta ao turista.

Foram listados no quadro 5 os aspectos positivos e negativos dos principais meios que podem ser úteis na interpretação ambiental da trilha do Salto São Jorge. 
Sendo assim, a interpretação ambiental feita por meio de folhetos, guias, painéis e centro de visitantes, nessa ordem, mostram-se como sendo as mais apropriadas para o local, dadas as condições atuais. O ideal seria a junção de todos os itens para um trabalho mais eficiente em relação à EA, geoturismo e geoconservação.

Quadro 5 - Vantagens e Desvantagens dos meios interpretativos para a trilha do Salto São Jorge

\begin{tabular}{|c|c|c|}
\hline & Vantagens & Desvantagens \\
\hline Painéis & $\begin{array}{l}\text { - As informações situam-se próximas aos pontos } \\
\text { de interpretação; } \\
\text { - Visitas com grau maior de liberdade, visitantes } \\
\text { estabelecem ritmo próprio; }\end{array}$ & $\begin{array}{l}\text { - Vulnerabilidade ao } \\
\text { vandalismo; } \\
\text { - Pode interferir visualmente } \\
\text { na paisagem; }\end{array}$ \\
\hline $\begin{array}{l}\text { Guias } \\
\text { turismo }\end{array}$ & $\begin{array}{l}\text { - Oportunidade de geração de renda para a } \\
\text { comunidade local; } \\
\text { - Diminuição da depredação, já que o guia orienta } \\
\text { a visita; } \\
\text { - Há possibilidade de se tirar dúvidas no momento } \\
\text { em que elas surgem; } \\
\text { - Flexibilidade para abordar diferentes aspectos de } \\
\text { elementos presentes na trilha conforme o tipo de } \\
\text { público; }\end{array}$ & $\begin{array}{l}\text { - A eficácia da interpretação } \\
\text { ambiental depende da } \\
\text { qualificação/ conhecimento do } \\
\text { guia; } \\
\text { - Os visitantes têm de } \\
\text { acompanhar o ritmo do guia ou } \\
\text { do grupo. }\end{array}$ \\
\hline $\begin{array}{l}\text { Publicações } \\
\text { (Folhetos) }\end{array}$ & $\begin{array}{l}\text { - Há possibilidade de exibir informações } \\
\text { detalhadas sobre a geologia e geomorfologia da } \\
\text { bacia hidrográfica do rio São Jorge; } \\
\text { - Não interfere no visual da paisagem; } \\
\text { - Apresenta um baixo custo financeiro; } \\
\text { - Os visitantes podem levar os folhetos para casa e } \\
\text { complementar informações. }\end{array}$ & $\begin{array}{l}\text { - O folheto, quando gratuito, } \\
\text { pode ser descartado como lixo } \\
\text { no próprio local. }\end{array}$ \\
\hline $\begin{array}{l}\text { Centro } \\
\text { visitantes }\end{array}$ & $\begin{array}{l}\text { - Possibilidade de exibir ao público, antes da } \\
\text { visitação, vídeos, fotografias, ou outros tipos de } \\
\text { atividades interativas sobre a bacia do rio São } \\
\text { Jorge, a APA da Escarpa Devoniana e outras UC’s } \\
\text { do Paraná; } \\
\text { - Possibilita ampla variedade de opções para } \\
\text { trabalhar aspectos de EA e geoturismo; }\end{array}$ & $\begin{array}{l}\text { - Requer elevado investimento } \\
\text { financeiro; }\end{array}$ \\
\hline
\end{tabular}


A trilha necessita de algumas intervenções para melhor atender às visitas. $\mathrm{O}$ fato de a área estar inserida nos domínios do Parque Nacional dos Campos Gerais ressalta ainda mais a importância da localidade e a necessidade de que sejam feitos reparos.

Ações de educação ambiental podem estar vinculadas à rede pública de ensino e a órgãos federais como o ICMBio (Instituto Chico Mendes de Conservação da Biodiversidade). Algumas sugestões são apresentadas para medidas que possam vir a melhorar o nível de satisfação do turista e conservar os recursos naturais que fazem da área do parque um cenário tão belo.

a) Renovação da infra-estrutura turística

Como a infra-estrutura atual da Fazenda Santa Bárbara está muito precária para atender turistas e estudantes, e algumas construções estão localizadas em área de preservação permanente (APP), as ações mais urgentes são no sentido de:

- Implantar placas com informações sobre a trilha;

- Instalar recipientes coloridos para coleta seletiva de lixo;

- Readequar os banheiros;

- Modificar a estrutura do centro de recepção;

b) Instalação de trilha suspensa para a recuperação do solo da trilha e evitar erosão

Recomenda-se que seja instalada uma trilha suspensa sobre as áreas planas e de relevo suave na trilha do Salto São Jorge (do início da trilha até o ponto de interpretação IV), tomando cuidado para manter a paisagem harmoniosa. O material mais indicado para construir esta estrutura é a madeira, que não destoa visualmente do ambiente natural.

c) Adaptações às pessoas portadoras de necessidades especiais

Para o público com algum tipo de deficiência física há limitações de acesso para a prática do turismo que podem ser transpostas com equipamentos como a própria 
trilha suspensa, além de rampas, corrimão, sinalização em Braille e banheiros adaptados.

Proporcionar uma área de lazer e contato com a natureza adaptadas às pessoas com deficiência física será um diferencial para qualquer local, uma vez que a maioria das unidades de conservação não leva em conta a sua acessibilidade. Tomar medidas para aumentar a inclusão social é uma prova de respeito às diferenças individuais e um exercício de cidadania.

d) Investir na interpretação ambiental da trilha por meio de visitas guiadas, painéis $e$ folhetos

Concorda-se com Rodrigues e Carvalho (2009), que afirmam que a interpretação da geodiversidade é o fundamento para uma estratégia de geoturismo. Para os autores, as paisagens e os fenômenos por si só passam despercebidos aos turistas, o que já não ocorre quando o ambiente está preparado com os instrumentos corretos. Como forma de contribuir com uma estratégia de interpretação ambiental do geossítio Salto São Jorge, um modelo de folheto interpretativo foi elaborado e segue em anexo.

\section{Considerações Finais}

As caminhadas em trilhas proporcionam a possibilidade de reflexão e do encontro consigo mesmo, quando podem ser feitas em silêncio, longe dos ruídos urbanos e com um distanciamento mínimo dos outros caminhantes e /ou do condutor. Aspectos relativos a valores emocionais e espiritualidade também podem aflorar nesse contato com o meio natural.

Estimular o uso das trilhas interpretativas ao cidadão é investir em saúde, bem estar e Educação Ambiental. Mas, de uma forma geral, o uso dos sítios naturais dos Campos Gerais, com fins turísticos, científicos e didáticos não é adequadamente organizado. Eles ainda são pouco conhecidos, não há orientação, estudos de capacidade de carga, planejamento e nem avaliação dos impactos ambientais.

Nos Campos Gerais encontram-se diversas trilhas que possuem um apelo geológico muito grande, além das paisagens belíssimas em que estão inseridas, porém elas não possuem nenhum instrumento interpretativo que auxilie os visitantes a irem além da apreciação estética. 
Além dos benefícios para os caminhantes, as trilhas podem trazer vantagens para as comunidades de entorno. A integração da comunidade local de Ponta Grossa na atividade geoturística (por meio de palestras, atividades educativas, mutirões, cursos de guia de geoturismo), faz com que haja valorização do patrimônio geológico.

Com o entendimento sobre as peculiaridades e importância das paisagens locais a nível nacional e mesmo internacional, se sobressai um sentimento de orgulho da própria terra, que fará com que a população se interesse pela educação patrimonial e dissemine cuidados ambientais. As pessoas que moram na cidade tornam-se atores sócio-econômicos que podem se beneficiar com o turismo, através de atividades que possibilitam geração de renda (venda de artesanatos e de alimentos, serviços de guias de turismo, estadia, entre outros).

Mas esse entendimento nem sempre é fácil. Um dos maiores desafios para aproximar os moradores e visitantes das informações a respeito da geologia e geomorfologia locais, é utilizar uma linguagem acessível, que seja compreensível ao público leigo.

\section{REFERÊNCIAS}

ANDRADE, W. J. Implantação e Manejo de Trilhas. In: Manual de Ecoturismo de Base Comunitária: ferramentas para um manejo responsável. Ed. da WWF - Brasil. Org.: MITRAUD, S. Brasília, DF. 2004.

ASSINE, M. L.; ALVARENGA, C. J. S.; PERINOTTO, J. A. J. Formação Iapó: glaciação continental no limite Ordoviciano/Siluriano da Bacia do Paraná. Revista Brasileira de Geociências. V. 28,1998. P. 51-60.

ASSINE, M. L. Fácies, icnofósseis, paleocorrentes e sistemas deposicionais da Formação Furnas no flanco sudeste da bacia do Paraná. Revista Brasileira de Geociências. V. 29, 1999. p. 357-370.

CIFUENTES, M. et al. Capacidad de carga turística de las áreas de uso público del Monumento Nacional Guayabo, Costa Rica. WWF Centroamerica, 1999.

COSTA, V. C. da. Propostas de manejo e planejamento ambiental de trilhas ecoturísticas: um estudo no Maciço da Pedra Branca - Município do Rio de Janeiro (RJ). Universidade Federal do Rio de Janeiro. Instituto de Geociências, Programa de Pós Graduação em Geografia. Tese. Rio de Janeiro, 2006. 283 p. 
GUIMARÃES, G. B.; MELO, M. S.; MOCHIUTTI, N. F., Desafios da Geoconservação nos Campos Gerais do Paraná. Revista do Instituto de Geociências USP. São Paulo, v.5 p.47-61. Outubro, 2009.

MAssuqueto, L. P., MELO, M. C. de, GuimarÃES, G. B., LOPES, M. C. Cachoeira de Santa Bárbara no Rio São Jorge, PR: Bela paisagem realça importante contato do embasamento com rochas glaciogênicas siluro-ordovicianas. Disponível em: http://vsites.unb.br/ig/sigep. Acesso: 27/11/2009.

NASCIMENTO, M. A. L., RUCHKYS, U. A., MANTESSO-NETO, V. Geodiversidade, Geoconservação e Geoturismo: trinômio importante para a proteção do patrimônio geológico. Catalogação da Publicação na Fonte. UFRN/ Biblioteca Central Zila Mamede, 2008.

RODRIGUES, A. B. Turismo e espaço: rumo a um conhecimento transdisciplinar. São Paulo: Hucitec: 1997.158 p.

RODRIGUES, J; CARVALHO, C. N. de. Geoturismo no Geopark Naturtejo - um passo na educação não formal. XIII Encontro Nacional de Educação em Ciências. Castelo Branco (Portugal), 2009.

SALVATI, S. S. Trilhas. Conceitos, Técnicas de Implantação e Impactos. Ecosfera, artigo publicado na Internet. Disponível em < http://ecosfera.sites.uol.com.br/trilhas.htm> Publicado em 21/set/ 2003. 
ANEXO - Folheto interpretativo com as características geológicas e geomorfológicas do Salto São Jorge
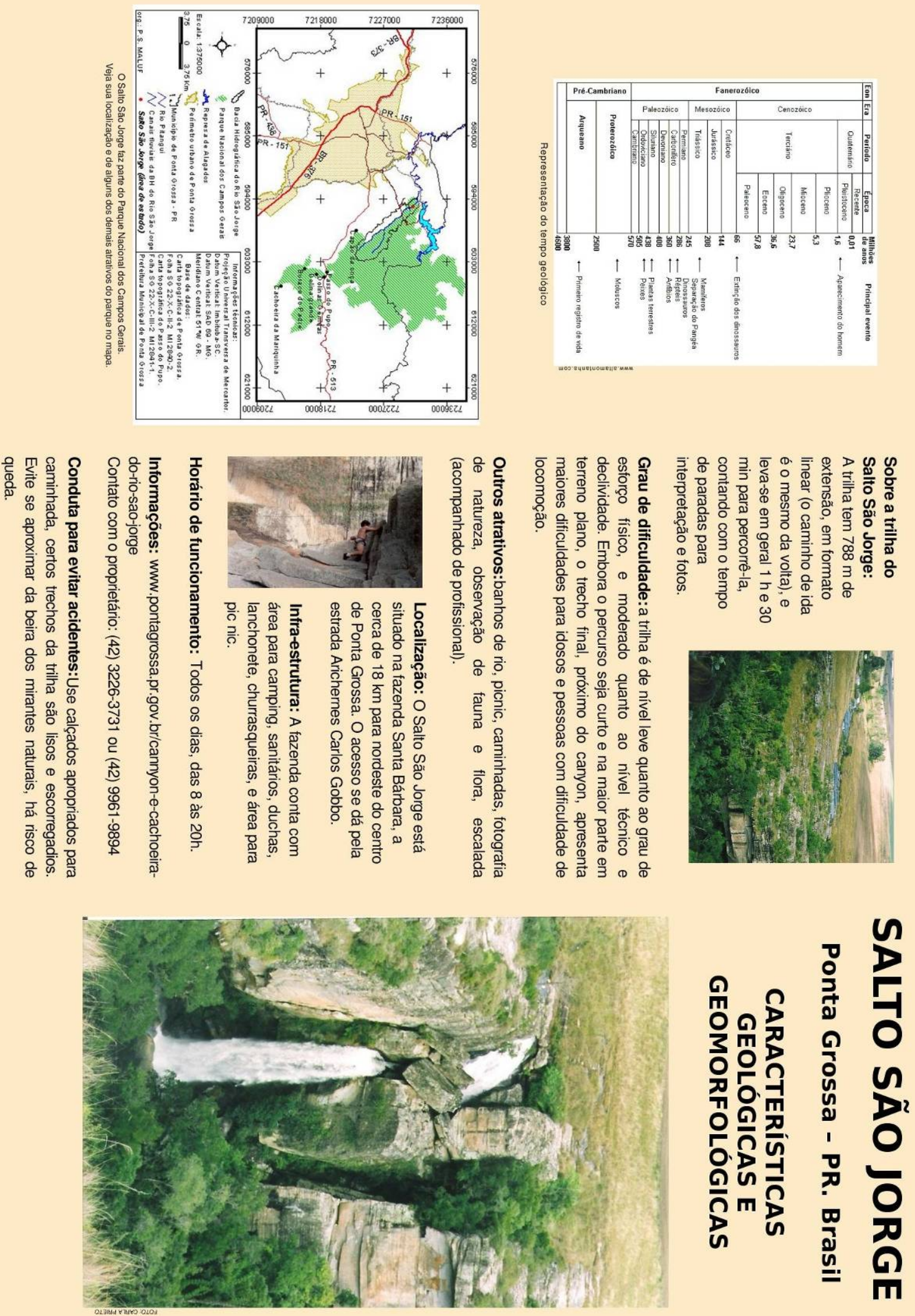

Geo UERJ - Ano 12, nº. 21, v. 2, 2ºmestre de 2010. www.geouerj.uerj.br/ojs ISSN 1981-9021 


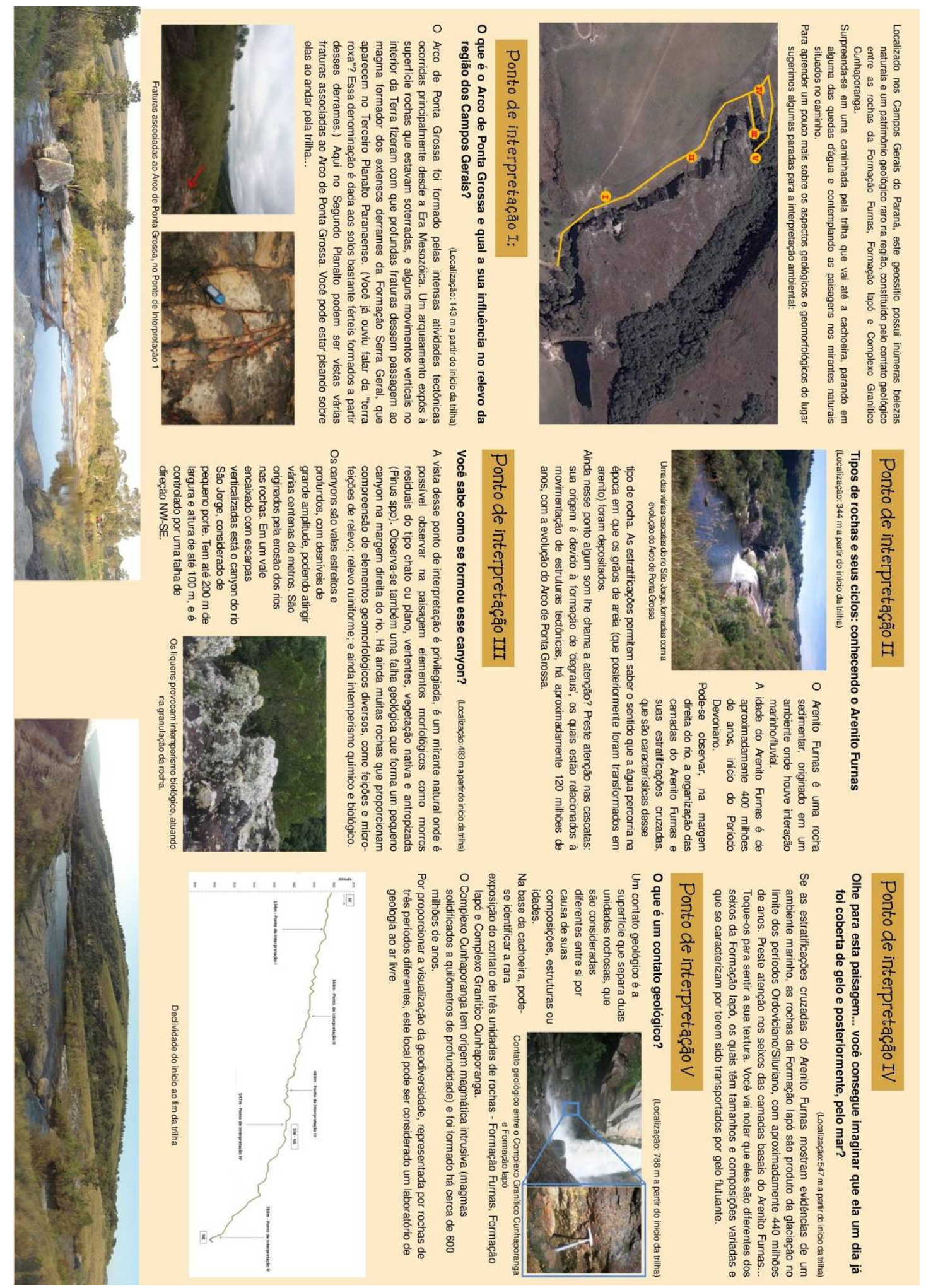

Geo UERJ - Ano 12, nº. 21, v. 2, $2^{\circ}$ semestre de 2010.

www.geouerj.uerj.br/ojs ISSN 1981-9021 